\title{
Did Einthoven invent a string galvanometer?
}

\author{
HOWARD B BURCHELL
}

From the Cardiovascular Division, University of Minnesota School of Medicine, Minneapolis, USA

Clinical electrocardiography belongs wholly to this century and stems from a paper of Willem Einthoven "Un nouveau galvanomètre" in 1901.1 The epochal work of Waller in $1887,{ }^{2}$ which showed that in man cardiac potentials could be recorded, had aroused Einthoven's interest and he devoted a large part of the next three decades to perfecting high fidelity methods of studying these potentials with instruments of his design.

In a recent review paper Cooper ${ }^{3}$ opined that Einthoven did not invent the string galvanometer and invited the inference that Einthoven did not give proper priority and credit to Ader. This raises semantic problems regarding the word "invent" and casts doubts on the veracity of Einthoven's account of his own work. It is not a new controversy and undoubtedly some writers, historically minded but not necessarily historical scholars, have used the word "invent" loosely. The hearsay opinion has been repeated in the literature: that Einthoven had his instrument built just by adapting already known equipment to his purpose. For instance, Barker (1910) in a long paper extolling the great clinical possibilities of electrocardiography, states "Einthoven of Leyden devised his string galvanometer based upon the suggestions of Ader." 4

My argument endorsing the propriety of the use of the word "invent" for Einthoven's instrument is based on the following points. The meaning of any word is defined by its common use. When a person does something in a new and effective way he is said to be inventive or ingenious. In the legal world, the word has implications for patent rights. There is no evidence that Einthoven had strong aspirations for a controlling patent. Snellen ${ }^{5}$ mentioned that any such claims would be abrogated by the publication in 1909 of the detailed specifications of his string galvanometer. I believe that within observed patent practices Einthoven's string galvanometer could have been patented because it was designed for a purpose and was a success in obtaining objectives not previously achieved. It was not a discovery and

Requests for reprints to Dr Howard B Burchell, 260 Woodlawn Avenue, St Paul, Minnesota, 55105, USA.

Accepted for publication 13 November 1986 much more than a gadget, and I submit would meet one encyclopaedic definition of an invention. ${ }^{6}$ Eine hoven (1903) condensed his views of his accoma plishments in these words. "I have constructed aip apparatus ... specifically designed to give direct regio istration of the human electrocardiogram which witt give true readings."7 Einthoven was generous if giving credit to other investigators. When he read paper before the Chelsea Medical Society (1912) he praised Waller and Lewis, and credited Waller with coining the term electrocardiogram: "It gives me especial pleasure to bring to remembrance here tha्f the human EKG was first recorded by a London. physiologist, Augustus D Waller, who also intro\% duced the term 'electrocardiogram' into science. "\$ Einthoven was unhappy with the editing of th: paper, as judged by his correspondence with Lewis.

Many scientists have apparently felt comfortablo with the use of the word "invention" for the Einto hoven instrument. Below is a list of short quotations from papers in which the word "invent" was used $\overrightarrow{0}$

Waller (1909): “Professor Einthoven's results with ... the extraordinarily sensitive galvanomete? he has invented ..."9

Lewis (1911): "The string galvanometer in its present form, the invention of Einthoven ...". ${ }^{10}$ I an obituary (1927) Lewis stated ". . . he moved to the principle of Ader's instrument ... constructed a gaE. vanometer greatly surpassing all previous instrig ments . . . created a piece of apparatus of unparalleled delicacy and accuracy." 11

A V Hill (1927) (in obituary): "The problem of recording these small and fleeting changes ... was solved in 1903 by the invention of the string gat vanometer."12

H B Williams (1947): “Accordingly, I agree witts you (A E Cohn) that the record should leave nog doubts on the score that Einthoven was the inventas of the electrocardiograph." 13

White (1949): "Finally in 1903 came the announcement of the invention of the accurate and practicable galvanometer (Einthoven)."14 (Curiv ously in the first and second editions of Heart Dis ease the word used was "discovery"; this wof changed to "invention" in the third edition.)

De Waart (1961): "Persevering in inventing and constructing his string galvanometer."15 
Burch and DePasquale (1964): "(Einthoven) will always be remembered as the inventor of the string galvanometer."16

Zachary Cope (1973): "The great development of this subject was largely due to the invention of the string galvanometer by Einthoven."17

Snellen (1983): "The mathematical correction (of the capillary electrometer tracings) although satisfactory was cumbersome and Einthoven therefore invented a new instrument." 18

The following are excerpts from work by other knowledgeable scientists. They are quoted because they use phrases or words that are equivalent to the word "invent":

Wenckebach (1927) (obituary): "Seine Grosstat, der er einen grossen Teil seines Lebens gewidmet, war das Saitengalvanometer."19

Samojloff (1930): "First of all, he is the creator of electrocardiography."20

Wilson (1940): (After work with capillary electrometer) "He was then able to determine the characteristics which an instrument suitable for his purpose (should have) and in 1903 he completed the first model of what has since been known as the string galvanometer."21

Barron (1950): "Realising the limitation of this method (capillary electrometer), he devised a more simple sensitive and accurate means of recording these fluctuating potentials." 22

Wiggers (1961): "Einthoven, therefore, undertook careful mathematical studies of the characteristics of moving coil galvanometers which eventually led him to employ the principle that a wire placed between two magnets bows when traversed by an electric current."23

Adrian et al (1976): "Einthoven introduced the string galvanometer in 1901." 24

The Nobel Committee, as is reflected by the presentation speech of Professor Johanssen, ${ }^{25}$ avoided any controversy: the justification of the award was for Einthoven's "discovery of the mechanism of the electrocardiogram" (a somewhat ambiguous phrase), and Einthoven's name was "linked to the design of a physical instrument" (the string galvanometer). Einthoven's Nobel lecture was given in German, but there is an English translation in the published Nobel lectures. The title of Einthoven's address was "The string galvanometer and

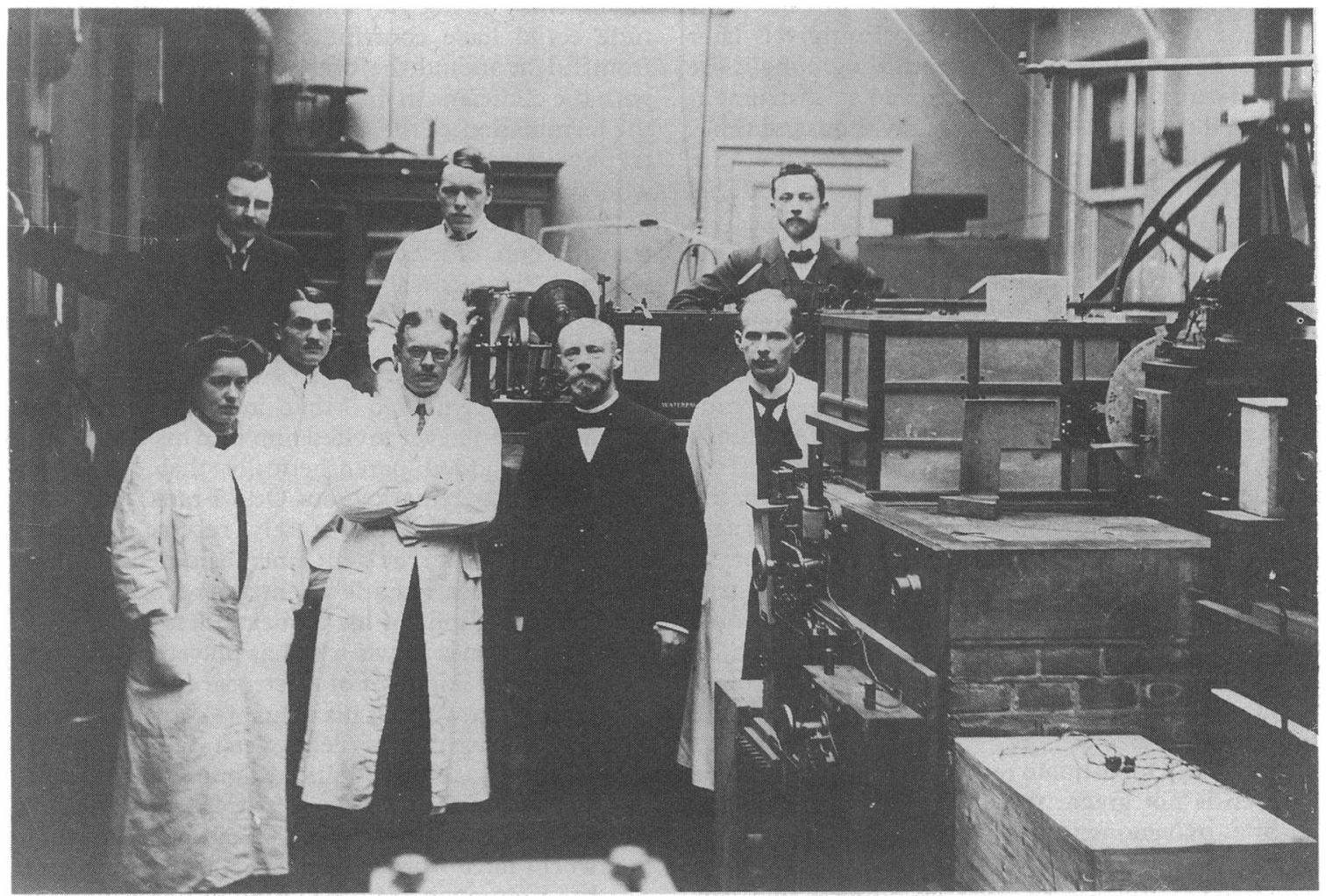

Figure A photograph taken in Einthoven's laboratory in about 1908 given to the author by Dr George Fahr. The string galvanometer in the background is obscured. Dr Fahr is the young man on the left and Dr Einthoven is appropriately in the centre and at the front. 
the measurement of the action currents of the heart." This oration, as Snellen has pointed out, "constitutes an important review of a lifetime's work." All the 26 figures also reflect the high technical quality which he demanded in his records.

Those of us who have worked with a string galvanometer may be at a disadvantage when it comes to objectively assessing this instrument; love and admiration for the instrument may have engendered a bias. As well as saying that Einthoven "did not invent the string galvanometer" Cooper also states that "he was not the first to describe the electrocardiogram."3 The claim that the PQRST wave form that was calculated by Einthoven from records taken on the capillary electrometer is the first true description of the electrocardiogram is not without support, as Professor Johanssen said in the Nobel presentation speech: "Einthoven can thus be named the discoverer of the real electrocardiogram." Einthoven added the $U$ wave later in 1903. This was a contribution of the string galvanometer. Waller expressed his admiration for Einthoven's records, and mentioned specifically that with his own 1887 apparatus, "the $P$ wave was not discernible." really correct to claim that Ader's galvanometer "was the type of instrument that Einthoven later used to introduce clinical electrocardiography": the implication being that Einthoven's instrument resembled that of Ader. It was many thousand times more sensitive, not merely an adaptation of the Ader instrument. Einthoven's credits to Ader in both his 1901 and 1909 papers $^{126}$ seem adequate to me. It is not reasonable to equate Einthoven's considerable improvements of the capillary electrometer with the profound changes that were needed to create his string galvanometer electrocardiograph from existing galvanometers. George Fahr, talking with me in his later years of his period with Einthoven, was candid in mentioning that Einthoven had rather clumsy hands and was somewhat secretive about his instrument when visitors came (this is contrary to the statements of others) (fig). Fahr, however, never said anything to impugn Einthoven's integrity or to imply that Einthoven had adapted Ader's instrument. In the late years (1920) there was some secrecy; access to the laboratory was forbidden on Fridays because of experimental wireless transmissions from Einthoven's son who was in the Dutch East Indies.

Burch and DePasquale recount a story, the source of which is not given, that Edelman manufactured the first galvanometers of the Einthoven design under an arrangement whereby Einthoven was to receive a $\$ 25$ royalty for each instrument that was sold. ${ }^{16}$ After adapting the instrument and using his knowledge of an existing Ader galvanometer Edel- man reneged on payment of the royalty. Whatever: the details of the falling out with Edelman, the even $\overrightarrow{\vec{E}^{2}}$ did initiate the development of companies in England $^{23}$ and the United States ${ }^{13}$ to manufacture the string galvanometer with Einthoven's "bless $\overline{\bar{n}}$. ing." Here then is prima facie evidence of a cor $\frac{D}{2}$ porate acknowledgement of Einthoven's rights to 에 patent.

Einthoven would probably have approved $\vec{P}$ Cooper's assertion that Bosscha "provided both $\vec{a}$ theoretical and practical support for Einthoven' $\omega$ work"; however, it still seems an exaggeration of Bosscha's role. He was not a teacher of Einthoven. of

The labelling of the wave forms according to the PQRST convention was never explained in writing by Einthoven. Waller tried to maintain his originaB rubric " $V_{1}$ and " $V_{2}$ " but he was unsuccessful ing gaining disciples of his cause. I believe that Hensongives the best description of the origins of the PQRST nomenclature, which was based on the geo-는 metrical convention of Descartes (by coincidence inw a book published in Leiden in 1637). ${ }^{27}$

My admiration of Willem Einthoven does not pre $-\overrightarrow{0}$ clude a suspicion that he might have been possessive about "his" string galvanometer and that this attitude could have contributed to his estrangemen from Edelman and the break up of his relationship with the clinicians in his hospital. Fahr relates ${ }^{28}$ tha跑 the termination of the collaboration with the hospi- $\frac{D}{2}$ tal physicians was engendered by an argument about who was to pay for the telephone line linking the hospital with the physiology laboratory for the transmission of electrocardiograms; another storyo was that "his occasional electrocardiographic arguments displeased the clinicians so much that in due course, the latter severed the connection." Wiggers $^{23}$ mentions in his encomium that Ottos Frank once remarked "that in visit to Leiden.". Einthoven had never invited him into his laboratory It may be added parenthetically that Einthoven made a similar remark about Otto Frank."

Successful individuals rarely receive universap acclaim for being true gentlemen as did Einthoven It is worth repeating a few sentences from the con 0 cluding paragraphs of his Nobel address:

"... Thomas Lewis who has played a great par: in the development of electrocardiography ... doubt that without his valuable contributions, should have the privilege of standing before you today", ... "in addition, innumerable othew workers in the field of electrocardiography have gained great merit ... investigators of the wholes world have worked together ... a new chapter has been opened in the study of heart diseases $\frac{\text { गे }}{\text { T. }}$ not by the work of a single investigator, but by that of many talented men ..." 
Einthoven's "invention", the instrument that he bequeathed to us, endures. If one needed a high fidelity, high sensitivity galvanometer with nearly perfect square wave response over a remarkable frequency range (perhaps to celebrate a diamond jubilee of the beginnings of electrocardiography in American hospitals), one could confidently take an ancient string apparatus off the shelf and expect it to work superbly.

\section{References}

1 Einthoven W. Un nouveau galvanomètre. Arch Neerl Sc Ex Nat 1901;6:625-33.

2 Waller $\mathrm{AD}$. A demonstration on man of electromotive changes accompanying the heart's beat. $f$ Physiol (Lond) 1887;8:227-34.

3 Cooper JK. Electrocardiography 100 years ago: origins, pioneers, and contributors. N Engl $f$ Med 1986;315:461-4.

4 Barker LF. Electrocardiography and phonocardiography. A collective review. Bull fohns Hopkins Hosp 1910;21:358-89.

5 Snellen HA. Selected papers on electrocardiography of Willem Einthoven, with bibliography, biographical notes and comments. Leiden: Leiden University Press, 1977:14.

6 Hall AR, Smith NAF. Invention. Encyclopedia Americana. New York: Americana Corporation, 1970; 15:326-38.

7 Einthoven W. Die galvanometrische Registrirung des menschlichen Elektrocardiogramms, zugleich eine Beurteilung der Anwendung des CapillarElektrometers in der Physiologie. Pflügers Arch 1903;99:472-80.

8 Einthoven W. The different forms of the human electrocardiogram and their signification. Lancet 1912;i:853-61.

9 Waller $\mathrm{AD}$. The electrocardiogram of man and dog as shown by Einthoven's string galvanometer. Lancet 1909;i:44-50.

10 Lewis T. The mechanism of the heart beat. London: Shaw and Sons, 1911:18.
11 Lewis T. Willem Einthoven [Obituary]. $\mathrm{Br}$ Med $\mathcal{f}$ 1927;ii:664-5.

12 Hill AV. Einthoven [Obituary]. Nature 1927;120:591.

13 Williams HB. (In paper by Cohn) Recollections concerning early electrocardiography in the United States. Bull Hist Med 1955;29:469-74.

14 White PD. Heart disease. 3rd ed. New York: Macmillan, 1949:173.

15 De Waart A. Einthoven commemoration. Am Heart $\mathcal{f}$ 1961;61:357-60.

16 Burch GE, DePasquale NP. A history of electrocardiography. Chicago: Year Book Medical Publishers, 1964.

17 Cope ZA. Auguste Desiré Waller (1856-1922). Med Hist 1973;17:380-6 (p 384).

18 Snellen HA. Two pioneers of electrocardiography. The correspondence between Einthoven and Lewis 1908-1926. Rotterdam: Donker Academic Publishers, 1983:11.

19 Wenckebach K. Willem Einthoven. Dtsch Med Wschr 1927;53:2176.

20 Samojloff A. Reminiscences of the late Professor Willem Einthoven. Am Heart f 1930;5:545-8.

21 Wilson FN. The electric currents associated with the heart beat. Selected papers. 1940. Ann Arbor: Edwards Brothers, 1954:1-10.

22 Barron SL. The development of the electrocardiogram in Great Britain. $\mathrm{Br}$ Med $\mathcal{F}$ 1950;i:720-5.

23 Wiggers CJ. Willem Einthoven (1860-1927). Some facets of his life and work. Circ Res 1961;9:225-34.

24 Adrian RH, Channell RC, Cohen T, Noble D. The Einthoven string galvanometer and the interpretation of the $\mathrm{T}$ wave of the electrocardiogram. $\mathcal{F}$ Physiol (Lond) 1976;63:67P-70P.

25 Johanssen JE. Nobel lectures. Physiology or medicine. 1922-1941. Amsterdam: Elsevier, 1965:89.

26 Einthoven W. Die Konstruktion des Saitengalvanometers. Pflugers Arch Ges Physiol 1909; 130:287-321.

27 Henson JH. Descartes and the ECG lettering series. $\mathcal{J}$ Hist Med Allied Sci 1971;26:181-6.

28 Fahr G. Einthoven. Ik wilde weten. George Fahr Festschrift. 80th birthday. Minneapolis: Lancet, 1962. 